\title{
Studies on broad spectrum corrosion resistant oxide coatings
}

\author{
SOMESWAR DATTA \\ Central Glass and Ceramic Research Institute, Kolkata 700 032, India
}

MS received 24 July 2000; revised 17 August 2001

\begin{abstract}
The corrosion resistant oxide coatings, developed and applied by the conventional vitreous enamelling techniques, showed superior resistance to a range of mineral acids at various strengths and temperatures, alkaline solutions, boiling water and chrome plating solutions. These coatings possess considerable abrasion and impact resistance as well as high thermal shock resistance. The properties of the coating system have been studied in detail and found to be strongly dependent on composition and processing parameters. These coatings have been characterized by $\mathrm{X}$-ray diffraction analysis and SEM studies. Some of the coating materials have been found to be biocompatible.
\end{abstract}

Keywords. Glass-ceramic; coating; vitreous enamelling; corrosion resistance; biocompatible.

\section{Introduction}

Corrosion resistant coating materials and their application technology are widely used by different industries. A number of coating systems are known ranging from metallic or polymeric to oxide based ceramics. Among them oxide based glassy and glass-ceramic coatings have additional advantages of chemical inertness, high temperature stability and superior mechanical properties as compared to other non-oxide coatings currently in use, for example, metallic, polymeric, etc (Van Vlack 1977; Phipps 1985; Datta 1998). Often, the coating systems used possess a very specific end use requirement with narrow range of selectivity. Modern engineering and technology demand such corrosion resistant coatings having a broad spectrum of effectivity under wider range of hostile environments. It is also essential that the corrosion resistant coatings should possess high resistance to thermal shock, abrasion and impact damage in order to lessen the chances of failure due to reasons other than corrosion (Briggs and White 1974). These improved vitreous or glass-ceramic type oxide coatings possessing enhanced mechanical, thermal and chemical properties may fulfil the requirements of modern engineering and technology (Behrenbeck and Patzke 1985).

The present paper describes the preparation, process of application and evaluation of a system of oxide based glass-ceramic coating materials. The coatings have been characterized and their properties have been evaluated as per various I.S., I.S.O. and D.I.N. standards. The coatings are designed for application on various grades of mild steel, stainless steel and titanium alloys.

Some of the coating materials are found to be biocompatible and the results indicate a strong possibility of a cementless fixation of artificial implants in human body.

\section{Experimental}

The coating system is based on inorganic oxides and can be applied on mild steel, stainless steel and titanium alloy by conventional vitreous enamelling process described elsewhere (Sen et al 1989).

Every individual process parameter related to batch making, glass melting, frit making and frit milling has been studied thoroughly and carefully to ascertain its reproducibility in a scale ranging from $500 \mathrm{~g}-25 \mathrm{~kg}$ of batches.

The approximate oxide composition of the coating system is as follows: $\mathrm{SiO}_{2}, 50 \cdot 0-65 \cdot 0 ; \mathrm{Li}_{2} \mathrm{O}, 0 \cdot 0-5 \cdot 0$; $\mathrm{Na}_{2} \mathrm{O}, 4 \cdot 0-14 \cdot 0 ; \mathrm{K}_{2} \mathrm{O}, 0 \cdot 0-10 \cdot 0 ; \mathrm{TiO}_{2}, 10 \cdot 0-20 \cdot 0 ; \mathrm{B}_{2} \mathrm{O}_{3}$, 6.0-15.0; $\mathrm{MgO}, 0 \cdot 0-3 \cdot 0 ; \mathrm{CaO}, 0 \cdot 0-3 \cdot 0 ; \mathrm{BaO}, 0 \cdot 0-3 \cdot 0$; $\mathrm{Al}_{2} \mathrm{O}_{3}, 0 \cdot 0-2 \cdot 5$; and $\mathrm{P}_{2} \mathrm{O}_{5}, 0 \cdot 0-3 \cdot 0$ in wt\%.

Different commercial grade raw materials have been used to prepare the coating materials and to study the effect of different ingredients on the properties and performance of the resultant oxide based coatings. These are quartz, soda ash, hydrated borax, boric acid, titania, rutile, tri-sodium phosphate, potassium nitrate, lithium carbonate, barium carbonate, di-ammonium hydrogen phosphate, ammonium di-hydrogen phosphate, etc.

The coating materials are prepared by melting the batch at $\sim 1300^{\circ} \mathrm{C}$ and the average yield of frit is $\sim 80 \%$ of theoretical value. Different combinations of mill additives have been used to study the ultimate coating properties to suit various specific end use requirements. However, for standard corrosion resistant coatings the combination of mill additives used are as follows: China clay, 3.0-10.0; 
quartz, $0 \cdot 0-15 \cdot 0 ;$ bentonite, $0 \cdot 0-1 \cdot 0 ;$ urea, $0 \cdot 0-0 \cdot 5$; $\mathrm{NaNO}_{2}, 0 \cdot 0-0.5 \mathrm{wt} \%$, and for bio-medical applications calcium hydroxy-apatite is also used.

To standardize the process parameters for preparation of coating materials suitable for application by conventional spraying or dipping method, the particle fineness, specific gravity and flowability of the resultant slip have been studied. The coating material after application and drying over the clean or ground coated metal surface was allowed to fuse at $820-900^{\circ} \mathrm{C}$. Subsequently, the coatings were heat-treated at $698^{\circ} \mathrm{C}$ for $1 \mathrm{~h}$.

The coating materials were analysed by differential thermal analysis (DTA) and thermogravimetric analysis (TGA) techniques (Netzsch STA 409C model instrument) to determine the growth temperature for subsequent crystallization. Typical DTA and TGA curves are shown in figure 1. The coefficient of thermal expansion of the coating materials was determined by a Shimadzu thermal analyser DT-30 model dilatometer. The resultant coatings were characterized by X-ray diffraction (XRD) analysis (P.W.-1010 X-ray crystallographic unit, using $\mathrm{Cu}-\mathrm{K}_{\alpha}$ radiation) and scanning electron microscopic (SEM) analysis (Cambridge Stereoscan S-250 electron microscope).

The properties of the resultant coatings are evaluated as per corresponding I.S., I.S.O. and DIN specifications for abrasion resistance (DIN: 51152, IS: 3972-1968), acid resistance (DIN: 51157, IS: 3972-1985, and ISO: 2743), alkali resistance (DIN: 51156, IS: 3972-1988, and ISO: 2745), boiling water resistance (DIN: 51165, ISO: 2744, ISO: 2733), resistance to hot chrome plating solution, thermal shock resistance (DIN: 51167, IS: 3972-1968), impact strength (IS: 3149-1994), leak test (IS: 31491994, DIN: 51163, and ISO: 2744), etc. Different compositions and mixtures of corrosive mediums and different exposure schedules are used to study the effectivity of the coatings in wider range of hostile environments.

For bio-medical applications, the coatings have been applied with calcium hydroxy-apatite, a natural bioactive material prepared from mammalian bones (Pal et al 1989, 1990), as mill additive. Coating was applied by dipping or spraying on precleaned pure titanium metal (Titan 12) or its alloy, Ti-6V-4Al. Small plugs of $1.6 \times 5 \mathrm{~mm}$ and head $3 \times 4 \mathrm{~mm}$ have been coated for implantation in rabbit femora. The blood compatibility of the implants has been studied using the method described in U.S. pharmacopoeia. The plugs have been implanted in the femur of adult rabbit by drilling $1.6 \mathrm{~mm}$ diameter holes and also as a SC-implant with a 22-gauge coated wire.

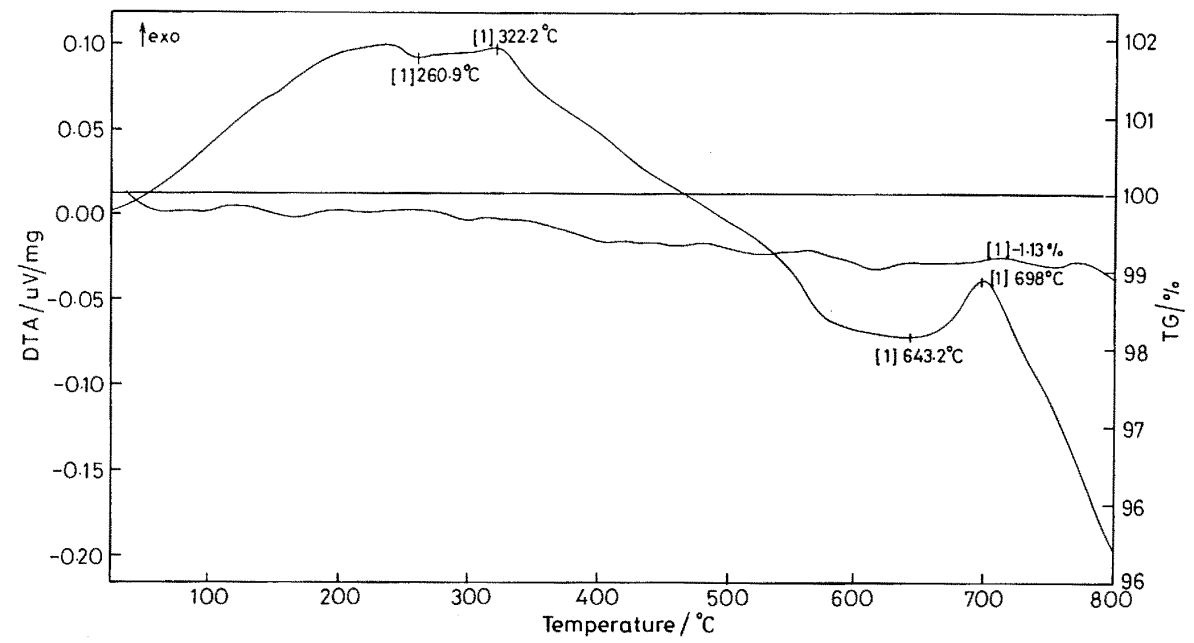

Figure 1. DTA and TGA curves of composition no. 4.

Table 1. Details of compositions studied (by wt.\%).

\begin{tabular}{lccccccc}
\hline $\begin{array}{l}\text { Composition } \\
\text { no. }\end{array}$ & $\mathrm{SiO}_{2}$ & $(\mathrm{Li}, \mathrm{Na}, \mathrm{K})_{2} \mathrm{O}$ & $(\mathrm{Mg}, \mathrm{Ca}, \mathrm{Ba}) \mathrm{O}$ & $\mathrm{B}_{2} \mathrm{O}_{3}$ & $\mathrm{TiO}_{2}$ & $\mathrm{P}_{2} \mathrm{O}_{5}$ & $\mathrm{Al}_{2} \mathrm{O}_{3}$ \\
\hline 1. & $65 \cdot 00$ & $12 \cdot 50$ & $2 \cdot 0$ & $7 \cdot 5$ & $12 \cdot 0$ & $1 \cdot 0$ & - \\
2. & $65 \cdot 00$ & $12 \cdot 50$ & $2 \cdot 5$ & $7 \cdot 5$ & $10 \cdot 0$ & - & $2 \cdot 5$ \\
3. & $58 \cdot 55$ & $13 \cdot 75$ & - & $8 \cdot 5$ & $17 \cdot 04$ & $2 \cdot 15$ & - \\
4. & $57 \cdot 10$ & $11 \cdot 50$ & $1 \cdot 1$ & $13 \cdot 2$ & $17 \cdot 1$ & - & - \\
5. & $57 \cdot 10$ & $11 \cdot 50$ & $1 \cdot 1$ & $13 \cdot 2$ & $17 \cdot 1$ & $2 \cdot 0$ & - \\
6. & $56 \cdot 60$ & $10 \cdot 50$ & $1 \cdot 1$ & $12 \cdot 2$ & $17 \cdot 1$ & $2 \cdot 0$ & $0 \cdot 5$ \\
7. & $54 \cdot 10$ & $11 \cdot 50$ & $2 \cdot 1$ & $13 \cdot 0$ & $16 \cdot 0$ & $3 \cdot 0$ & $0 \cdot 2$ \\
\hline
\end{tabular}


Table 2. Effect of raw materials on coating properties.

\begin{tabular}{|c|c|c|c|c|c|}
\hline Opacifier used & $\begin{array}{l}\text { Firing } \\
\text { temperature }\end{array}$ & Colour & Thermal history & $\begin{array}{c}\text { Acid resistance } \\
(\text { loss in weight } \\
\left.\text { value in } \mathrm{mg} / \mathrm{dm}^{2}\right)\end{array}$ & $\begin{array}{l}\text { Abrasion resistance } \\
\text { (loss in weight value) }\end{array}$ \\
\hline $12 \% \mathrm{TiO}_{2}$ & $820-840^{\circ} \mathrm{C}$ & Bluish white & Virgin & 70 & $1.6 \mathrm{mg} / \mathrm{cm}^{2}$ \\
\hline $12 \% \mathrm{TiO}_{2}$ & $820-840^{\circ} \mathrm{C}$ & Bluish white & Heat-treated & 40 & - \\
\hline $17 \cdot 1 \% \mathrm{TiO}_{2}$ & $840-860^{\circ} \mathrm{C}$ & Milky white & Virgin & 30 & $1.8 \mathrm{mg} / \mathrm{cm}^{2}$ \\
\hline $17 \cdot 1 \% \mathrm{TiO}_{2}$ & $840-860^{\circ} \mathrm{C}$ & Milky white & Heat treated & 15 & \\
\hline $17 \cdot 1 \%$ Rutile & $840-860^{\circ} \mathrm{C}$ & Creamy yellow & Virgin & 10 & $1.6 \mathrm{mg} / \mathrm{cm}^{2}$ \\
\hline $17 \cdot 1 \%$ Rutile & $840-860^{\circ} \mathrm{C}$ & Creamy yellow & Heat-treated & 5 & - \\
\hline $17 \cdot 1 \% \mathrm{TiO}_{2}+2 \% \mathrm{P}_{2} \mathrm{O}_{5}$ & $820-840^{\circ} \mathrm{C}$ & Dull white & Virgin & 50 & $1.4 \mathrm{mg} / \mathrm{cm}^{2}$ \\
\hline $17 \cdot 1 \% \mathrm{TiO}_{2}+2 \% \mathrm{P}_{2} \mathrm{O}_{5}$ & $820-840^{\circ} \mathrm{C}$ & Dull white & Heat treated & 60 & - \\
\hline
\end{tabular}

Table 3. Change in acid resistance property with composition and mill addition of quartz.

\begin{tabular}{|c|c|c|c|c|}
\hline Test no. & $\begin{array}{l}\text { Opacifier } \\
\text { used }\end{array}$ & $\begin{array}{l}\text { Quartz addition } \\
\text { (wt.\%) }\end{array}$ & $\begin{array}{l}\text { Heat treatment } \\
\text { given }\end{array}$ & $\begin{array}{c}\text { Weight loss } \\
\left(\mathrm{mg} / \mathrm{dm}^{2}\right)\end{array}$ \\
\hline 1. & $17 \cdot 1 \% \mathrm{TiO}_{2}$ & $0 \cdot 0$ & No & 35 \\
\hline 2. & $17 \cdot 1 \% \mathrm{TiO}_{2}$ & $0 \cdot 0$ & Yes & 30 \\
\hline 3. & $17 \cdot 1 \% \mathrm{TiO}_{2}$ & $2 \cdot 5$ & No & 33 \\
\hline 4. & $17 \cdot 1 \% \mathrm{TiO}_{2}$ & $2 \cdot 5$ & Yes & 20 \\
\hline 5. & $17 \cdot 1 \% \mathrm{TiO}_{2}$ & $5 \cdot 0$ & No & 15 \\
\hline 6. & $17 \cdot 1 \% \mathrm{TiO}_{2}$ & $5 \cdot 0$ & Yes & 6 \\
\hline 7. & $17 \cdot 1 \% \mathrm{TiO}_{2}$ & $7 \cdot 5$ & No & 18 \\
\hline 8. & $17 \cdot 1 \% \mathrm{TiO}_{2}$ & $7 \cdot 5$ & Yes & 10 \\
\hline 9. & $17 \cdot 1 \% \mathrm{TiO}_{2}$ & $10 \cdot 0$ & No & $12 \cdot 7$ \\
\hline 10. & $17 \cdot 1 \% \mathrm{TiO}_{2}$ & $10 \cdot 0$ & Yes & 10 \\
\hline 11. & $17 \cdot 1 \% \mathrm{TiO}_{2}$ & $12 \cdot 5$ & No & $8 \cdot 5$ \\
\hline 12. & $17 \cdot 1 \% \mathrm{TiO}_{2}$ & $12 \cdot 5$ & Yes & 10 \\
\hline 13. & $17 \cdot 1 \% \mathrm{TiO}_{2}$ & $15 \cdot 0$ & No & 50 \\
\hline 14. & $17 \cdot 1 \% \mathrm{TiO}_{2}$ & $15 \cdot 0$ & Yes & 35 \\
\hline 15. & $17 \cdot 1 \%$ Rutile & $0 \cdot 0$ & No & 16 \\
\hline 16. & $17 \cdot 1 \%$ Rutile & $0 \cdot 0$ & Yes & 6 \\
\hline 17. & $17 \cdot 1 \%$ Rutile & $5 \cdot 0$ & No & 6 \\
\hline 18. & $17.1 \%$ Rutile & $5 \cdot 0$ & Yes & $4 \cdot 5$ \\
\hline
\end{tabular}

Table 4. Effect of mill added quartz on alkali and abrasion resistance.

\begin{tabular}{ccccc}
\hline Test no. & $\begin{array}{c}\text { Quartz addition } \\
(\text { wt.\% })\end{array}$ & $\begin{array}{c}\text { Heat treatment } \\
\text { given }\end{array}$ & $\begin{array}{c}\text { Alkali resistance } \\
\text { loss in wt } \\
\left(\mathrm{mg} / \mathrm{dm}^{2}\right)\end{array}$ & $\begin{array}{c}\text { Abrasion resistance } \\
\text { loss in wt } \\
\left(\mathrm{mg} / \mathrm{cm}^{2}\right)\end{array}$ \\
\hline 1. & $0 \cdot 0$ & No & 10 & 1.8 \\
2. & $0 \cdot 0$ & Yes & $4 \cdot 8$ & 1.67 \\
3. & $5 \cdot 0$ & No & $3 \cdot 7$ & 1.47 \\
4. & $5 \cdot 0$ & Yes & $1 \cdot 0$ & 1.5 \\
5. & 7.5 & No & $1 \cdot 8$ & 1.7 \\
6. & 7.5 & Yes & $1 \cdot 1$ & 1.8 \\
7. & $10 \cdot 0$ & No & 9 & 1.75 \\
8. & 10.0 & Yes & $5 \cdot 3$ & 1.93 \\
9. & 12.5 & No & 10.5 & 1.83 \\
10. & 12.5 & Yes & 4.2 & 1.96 \\
\hline
\end{tabular}




\section{Results and discussion}

The methodology adopted for development of a broad spectrum corrosion resistant coating involves two distinct steps. The first is to develop a corrosion resistant coating material by designing a suitable glass composition (Andrews 1961; Vargin 1966; Datta 1995). The second stage involves modification in processing of the developed coating material to yield a broad spectrum corrosion resistant coating.

\subsection{Coating material preparation}

A series of suitably designed alkali-boro-silicate compositions containing titania (opacifier) and other ingredients (as shown in table 1) was studied with respect to their coating properties.

The effect of the raw materials (especially opacifiers and nucleating agent) on resultant coating properties are shown in table 2. The firing temperature, colour and functional properties change with coating material composition.

Table 5. Corrosion resistance of heat-treated $5.0 \mathrm{wt} \%$ quartz added coating.

\begin{tabular}{llccc}
\hline Test no. & \multicolumn{1}{c}{ Corrosive agent } & $\begin{array}{c}\text { Temperature } \\
\left({ }^{\circ} \mathrm{C}\right)\end{array}$ & $\begin{array}{c}\text { Duration } \\
(\mathrm{h})\end{array}$ & $\begin{array}{c}\text { Weight loss } \\
\left(\mathrm{mg} / \mathrm{dm}^{2}\right)\end{array}$ \\
\hline 1. & $11 \% \mathrm{HCl}$ & 100 & $2 \cdot 5$ & $6 \cdot 0$ \\
2. & $11 \% \mathrm{HNO}_{3}$ & 100 & $2 \cdot 5$ & $11 \cdot 0$ \\
3. & $11 \% \mathrm{H}_{2} \mathrm{SO}_{4}$ & 100 & $2 \cdot 5$ & $10 \cdot 8$ \\
4. & $10 \% \mathrm{NaOH}$ & 100 & $2 \cdot 0$ & $85 \cdot 6$ (liquid) \\
5. & $10 \% \mathrm{NaOH}$ & 100 & $2 \cdot 0$ & $1 \cdot 8$ (vapour) \\
6. & Conc. $\mathrm{HCl}$ & 120 & $2 \cdot 0$ & $9 \cdot 5$ \\
7. & Conc. $\mathrm{HNO}_{3}$ & 130 & $2 \cdot 0$ & $9 \cdot 8$ \\
8. & Conc. $\mathrm{H}_{2} \mathrm{SO}_{4}$ & 360 & $2 \cdot 0$ & 23 \\
9. & Chrome plating & 80 & $2 \cdot 0$ & $5 \cdot 2$ \\
& solution & & & \\
\hline
\end{tabular}

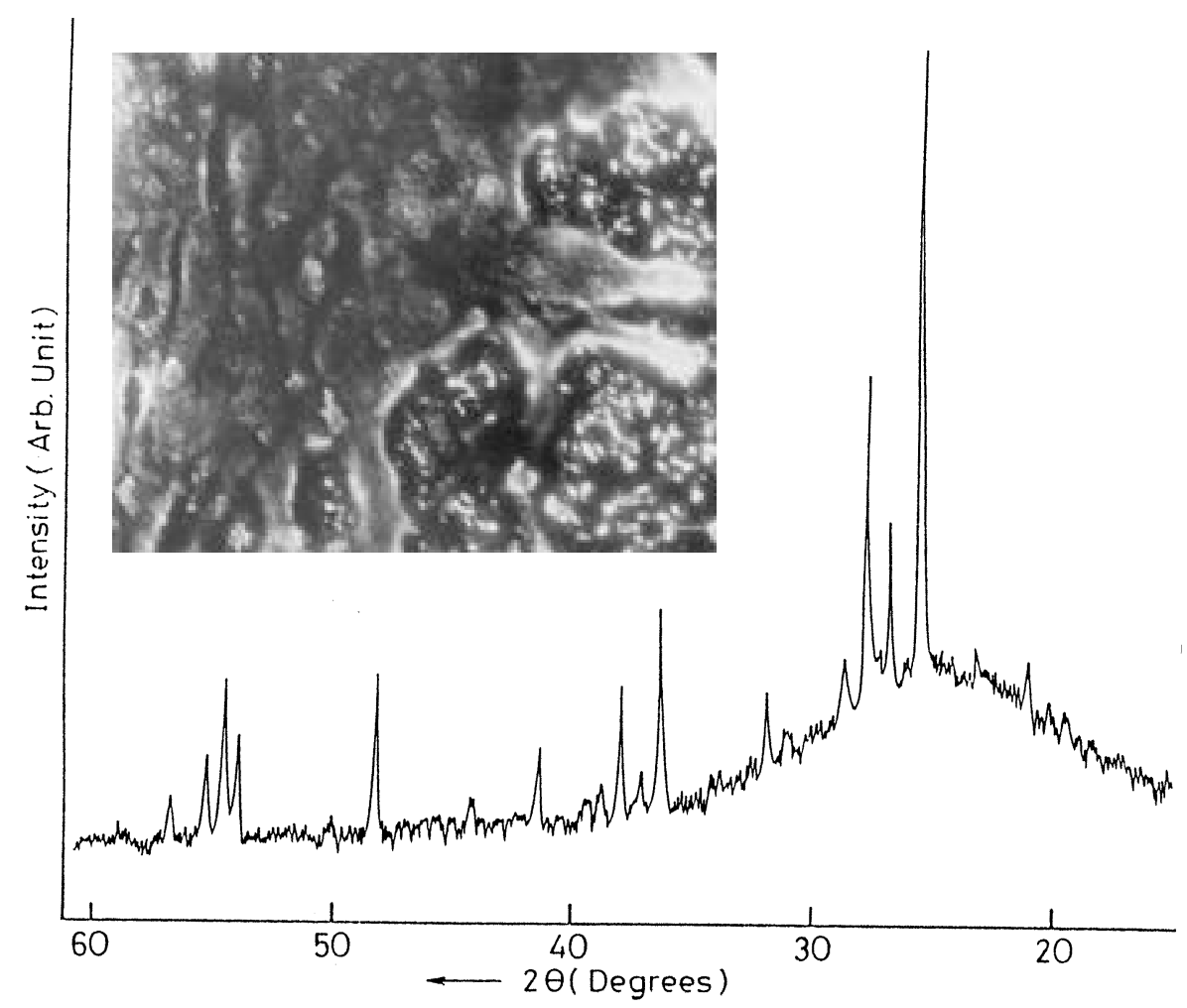

Figure 2. XRD pattern and scanning electron micrograph (inset) of the coating (composition no. 4). 
Initially corrosion resistance against $11 \%$ boiling $\mathrm{HCl}$ was used as a tool for comparison between various coating materials. Finally abrasion resistance (measured as loss in weight value) and coating appearance (colour and surface finishing) was considered for selection of the best coating. The coating material composition with $17.1 \%$ by wt. of $\mathrm{TiO}_{2}$ (composition number 4) was selected and used in subsequent studies during this investigation.

\subsection{Coating material characterization}

The coating material (no. 4) is a yellowish brown transparent glass which upon heat treatment yields a milky white glass-ceramic material. The specific gravity of the coating material is 2.516 and after conversion to glassceramic it increases to $2 \cdot 554$. The thermal expansion coefficient of the material is $\sim 75 \times 10^{-7}$ measured from room temperature to $400^{\circ} \mathrm{C}$. After conversion to glassceramic the thermal expansion coefficient remains same when measured in same temperature interval. Thus crystallization of this glassy coating does not introduce any sort of stress or strain.

\subsection{Processing of the coating material}

For conventional application by vitreous enamelling process, the milling fineness, specific gravity and flow characteristics of the processed coating material (slip) were studied and it was observed that the optimum range of specific gravity is 1.62-1.64. For application by dipping, a rather coarser particle size (-200 mesh B.S. sieve) is preferred to yield a thicker application $(>100 \mu)$ and for spraying, a more dilute fine particle slip $(-300$ mesh B.S. sieve) can be used to yield a thin coat $(\sim 50$ $80 \mu)$ application.

The firing temperature and time have been found to influence corrosion resistance property of the coating. The corrosion resistance property increases with increase in firing temperature and time.

\subsection{Effect of mill addition}

The functional properties of the resultant coating strongly depend on mill additives used for making slip. The most effective mill additive reported in the literature to improve the acid resistance is finely ground quartz

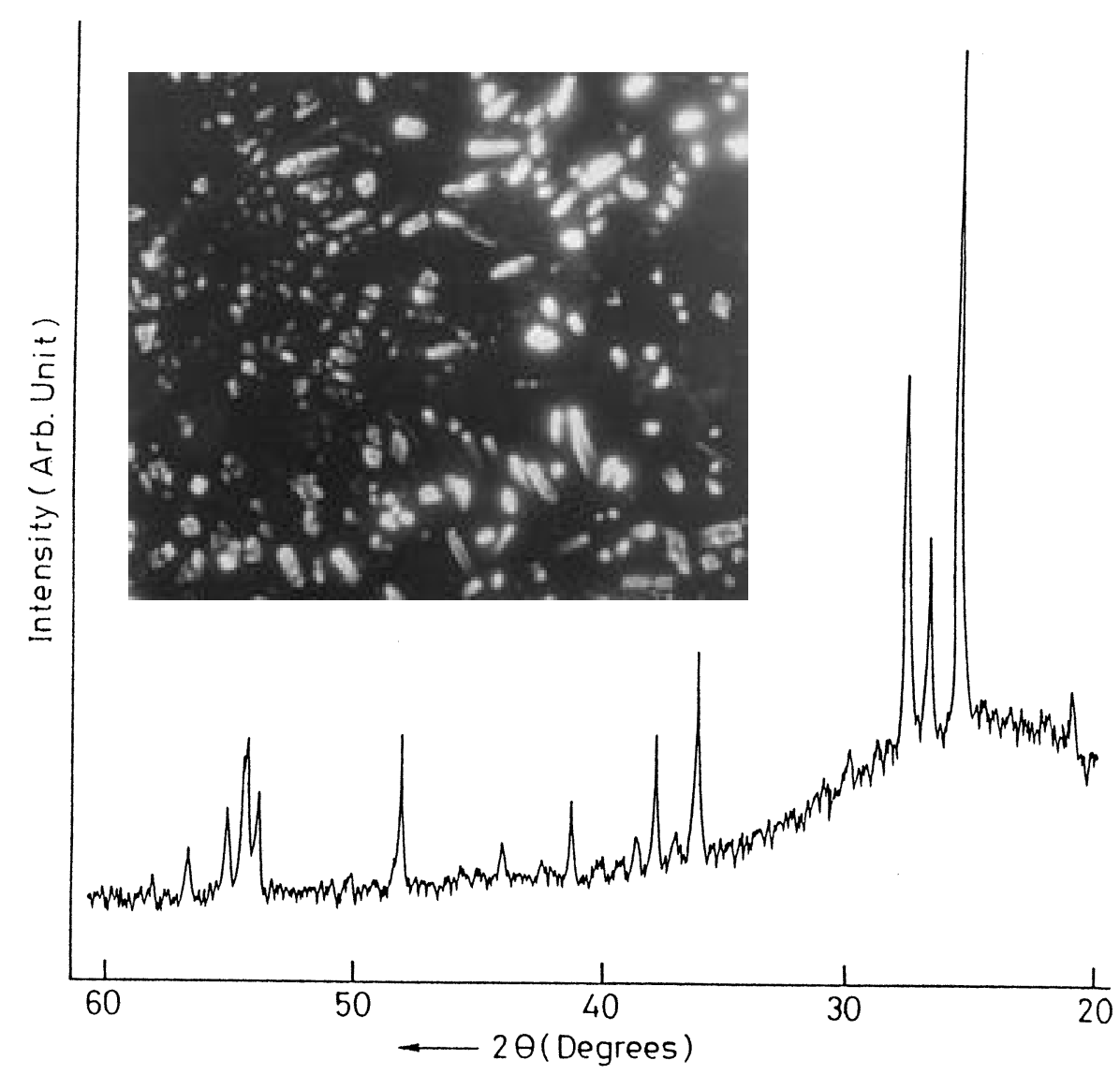

Figure 3. XRD pattern and scanning electron micrograph (inset) of heat-treated coating (composition no. 4). 
(Svetlov et al 1983). The effects of quartz addition on acid resistance property of the resultant coatings have been studied in detail. The results are reported in table 3 . It was found that the particle size of quartz powder added strongly influences the rheological properties of the resulting slip. Consequently, the firing temperature and surface finish of the coating change influencing the ultimate coating properties. The quartz powder of -400 mesh (B.S. sieve) and particle size $(\sim 35 \mu \mathrm{m})$ gives the optimum coating properties. The results from table 3 clearly indicate that quartz addition up to a certain limit (5-10 wt $\%$ ) increases the acid resistance property without any adverse effect on other properties. The same trend has also been observed with frit made from rutile instead of $\mathrm{TiO}_{2}$. Further, addition of quartz powder adversely affects some of the coating properties. This may be due to increasing firing temperature and refractoriness of the resulting coatings. The results presented in table 4 indicates that alkali resistance and abrasion resistance properties increase with initial addition of quartz but further addition decreases the alkali and abrasion resistance. Heat treatment increases alkali resistance in all the

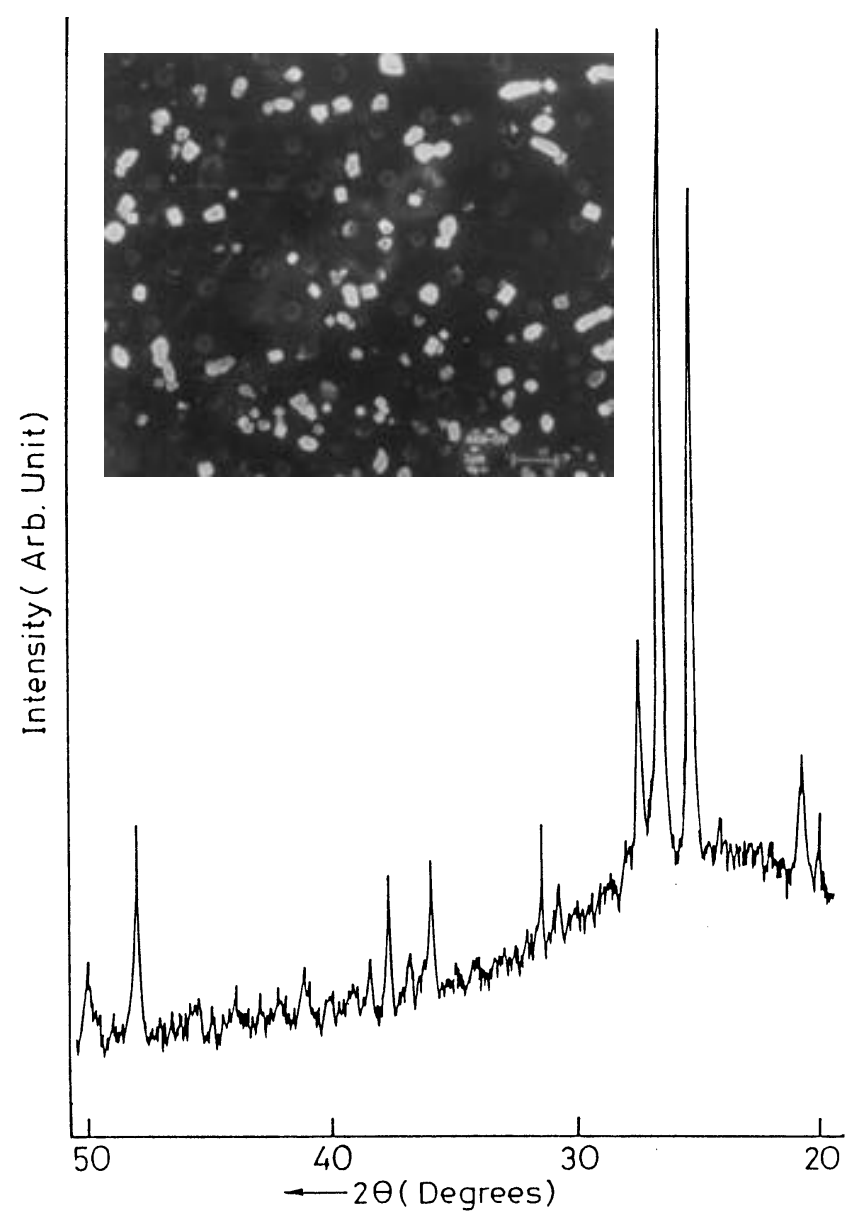

Figure 4. XRD pattern and scanning electron micrograph (inset) of coating (composition no. 4 with $5 \%$ quartz). cases studied. Abrasion resistance of the heat treated coatings changes according to the change in the microstructure of the coating matrix.

The coating resists thermal shock at $400-450^{\circ} \mathrm{C}$ (10 cycles) without any damage. The impact strength of the coating was found to be $20-25 \mathrm{~kg}-\mathrm{cm}$ ('falling ball' method). Both the results are superior to that for conventional enamels (thermal shock resistance: $350-400^{\circ} \mathrm{C}$ (6 cycles) and impact strength: 10 $12 \mathrm{~kg} \cdot \mathrm{cm})$.

The effect of heat treatment at growth temperature for $1 \mathrm{~h}$ varies with composition. The results reported in table 2 showed that addition of nucleating agent, $\mathrm{P}_{2} \mathrm{O}_{5}$ adversely affects the acid resistance property on crystallization.

\subsection{Coating performance in broad spectrum of corrosive environments}

Table 5 shows the results of corrosion resistance at different temperatures and different corrosive environments. Clearly the coating is very effective even in very strong acidic environment and substantially high temperature. However, the coating is not that effective in direct contact with hot alkali solution although it can withstand the action of the vapour phase. This can be possibly due to existence of a silicic acid network formation resulting from initial reaction of acids on excess $\mathrm{SiO}_{2}$ within the coating surface which prevent further penetrating action of acids but fail to perform so with hot alkali solutions.

\subsection{Coating characterization}

The coatings have been characterized by X-ray diffraction and scanning electron microscopic studies. The X-ray diffraction patterns of different coatings are shown in figures 2-7. X-ray diffraction analysis indicates presence of three types of crystalline phases: anatase, rutile and quartz, in both virgin and heat-treated coatings (Powder diffraction file 1967). The relative intensities as obtained from XRD pattern of the initial coating vary in the order of anatase > rutile > quartz. Heat treatment increases relative intensities of quartz and rutile. In presence of mill addition of quartz, heat treatment increases relative intensity of anatase but intensity of the rutile peak decreases. This effect was more prominent in case of 5\% quartz used as mill addition. In this case, the initial strongest peak was due to quartz but after heat treatment the anatase peak became the strongest and the intensity of rutile peak decreased, as a result abrasion resistance of the coating decreased. The scanning electron microscopic studies also corroborate the X-ray analysis data. The micrographs shown in insets of figures 2-7 show presence 
of three types of crystals, e.g. cubic shaped quartz crystals, small rod like rutile crystals and needle shaped anatase crystals. Crystal size of anatase is $0.5-1.0 \mu \mathrm{m}$ in length and that of other two phases are $0 \cdot 1-0 \cdot 2 \mu \mathrm{m}$ in length. The crystals are almost homogeneously distributed throughout the coating matrix. The general difference between the virgin and heat-treated micrographs being the volume fraction of crystalline phases are slightly more and rutile and quartz crystals have marginally greater size $(0.2 \mu \mathrm{m}$ compared to $0 \cdot 1 \mu \mathrm{m})$.

\subsection{Bio-medical properties evaluation}

For cementless fixation of artificial implants in human body, it is essential that the coating should contain a bone like material e.g. calcium hydroxyapatite. For substantial tissue ingrowth the coating should be porous and very thin in order to withstand the enormous compressive loading during subsequent movement of the organ. Above all it is absolutely necessary that the coating should be biocompatible (Hulbert et al 198283). The coating reported here is relatively thin $(50-80 \mu \mathrm{m})$, porous and sufficiently adherent towards scratches. The X-ray diffraction analysis indicates the presence of calcium hydroxyapatite crystals in the coating matrix. The blood compatibility of the coating has been found to be the same as that of pure titanium metal. In case of fixation of coated titanium plugs in the femur bone of adult rabbits the plugs were fixed with respective bones after 8 weeks and there was no adverse body reaction. This indicates a bright

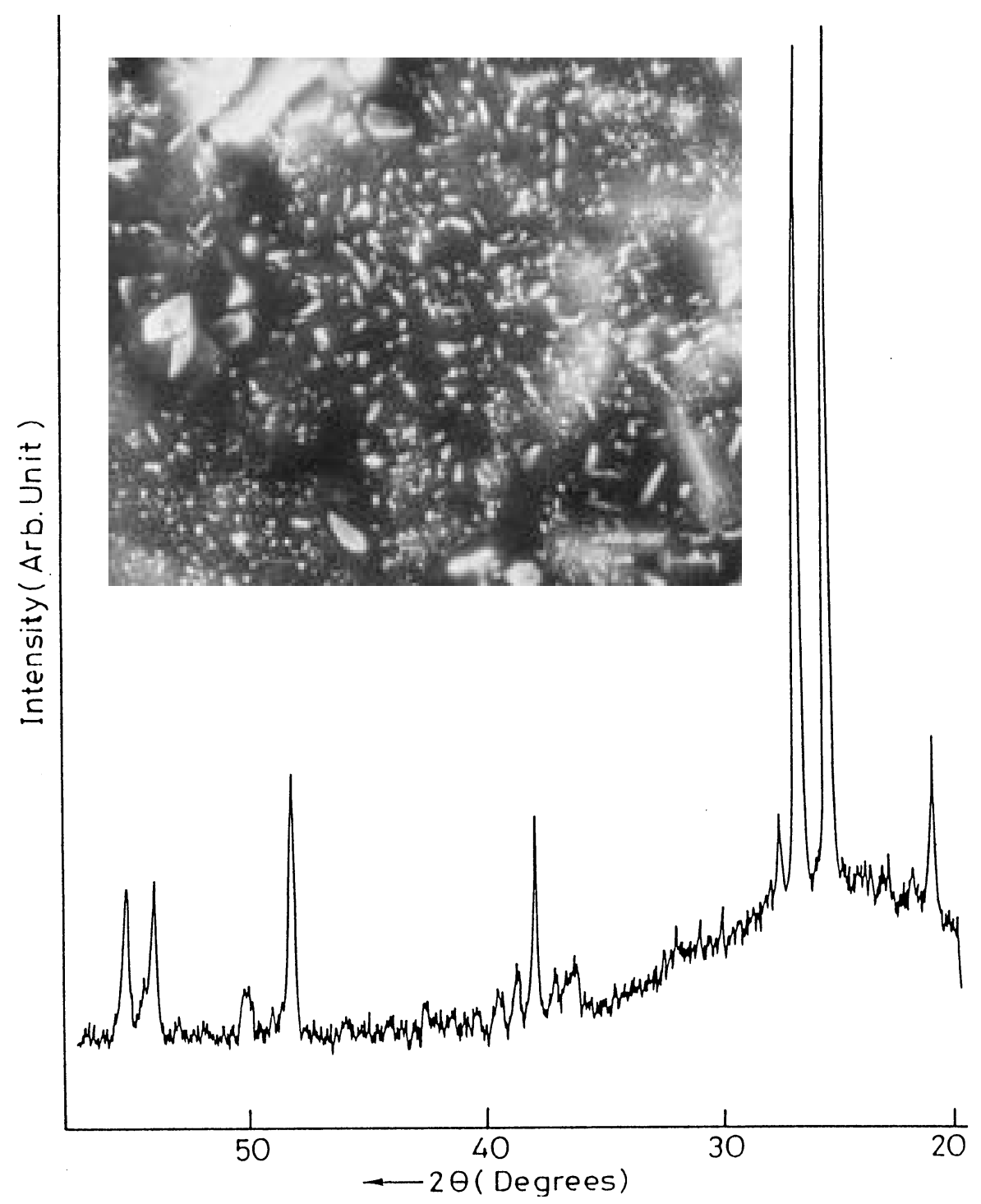

Figure 5. XRD pattern and scanning electron micrograph (inset) of heat-treated coating (composition no. 4 with $5 \%$ quartz). 


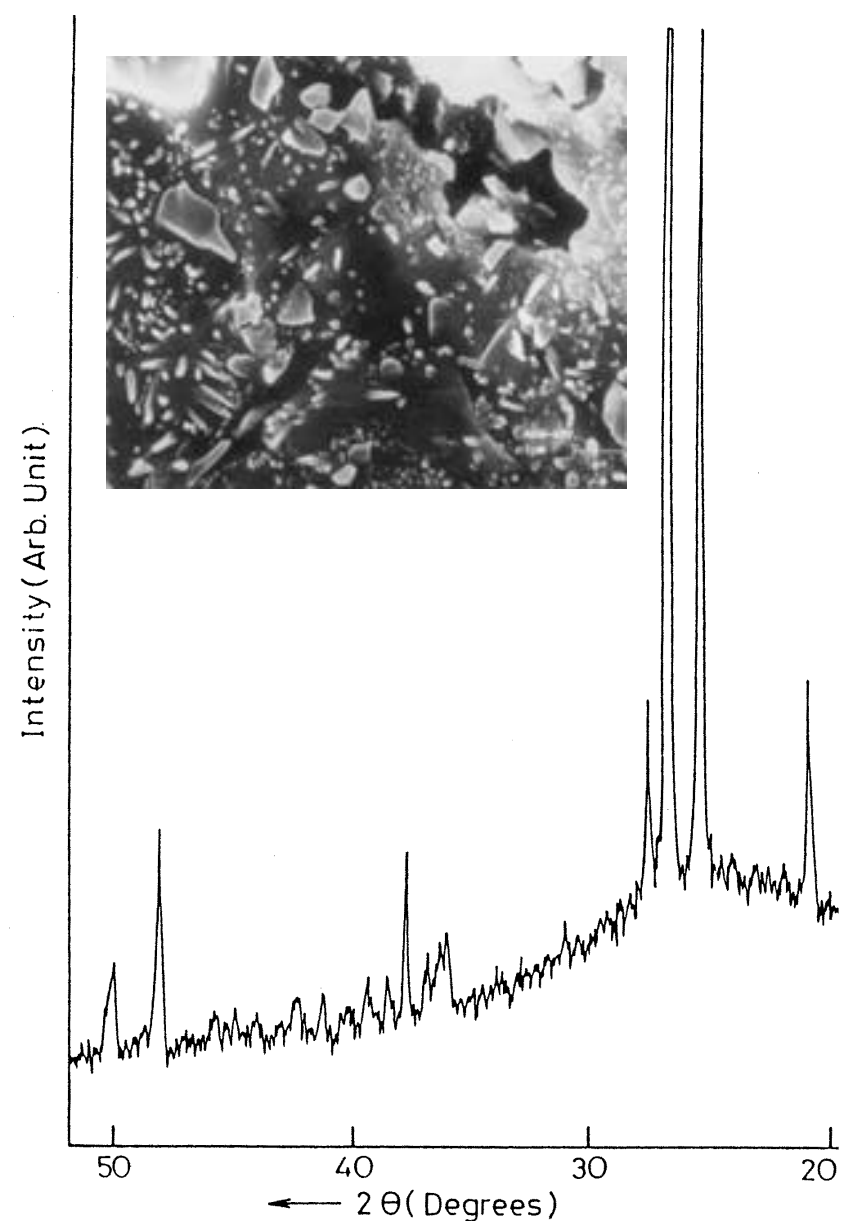

Figure 6. XRD pattern and scanning electron micrograph (inset) of coating (composition no. 4 with $10 \%$ quartz).

possibility for use of this coating material as a potential bioceramic material.

\section{Conclusion}

The unique features of the oxide based coating system can be listed as follows:

(I) The coating material can be applied by simple vitreous enamelling process over a range of metals and alloys.

(II) The coating material possesses reasonably low melting $\left(1200-1400^{\circ} \mathrm{C}\right)$ and processing $\left(820-860^{\circ} \mathrm{C}\right)$ temperature leading to less energy consumption during preparation and application.

(III) The resultant coatings can be tailored to possess very good corrosion resistance towards a range of corrosive medium in wide temperature range to combat different hostile environments.

(IV) The coating material is tested to be bio-compatible and suitable for cementless fixation of artificial implants on mammalian bones.

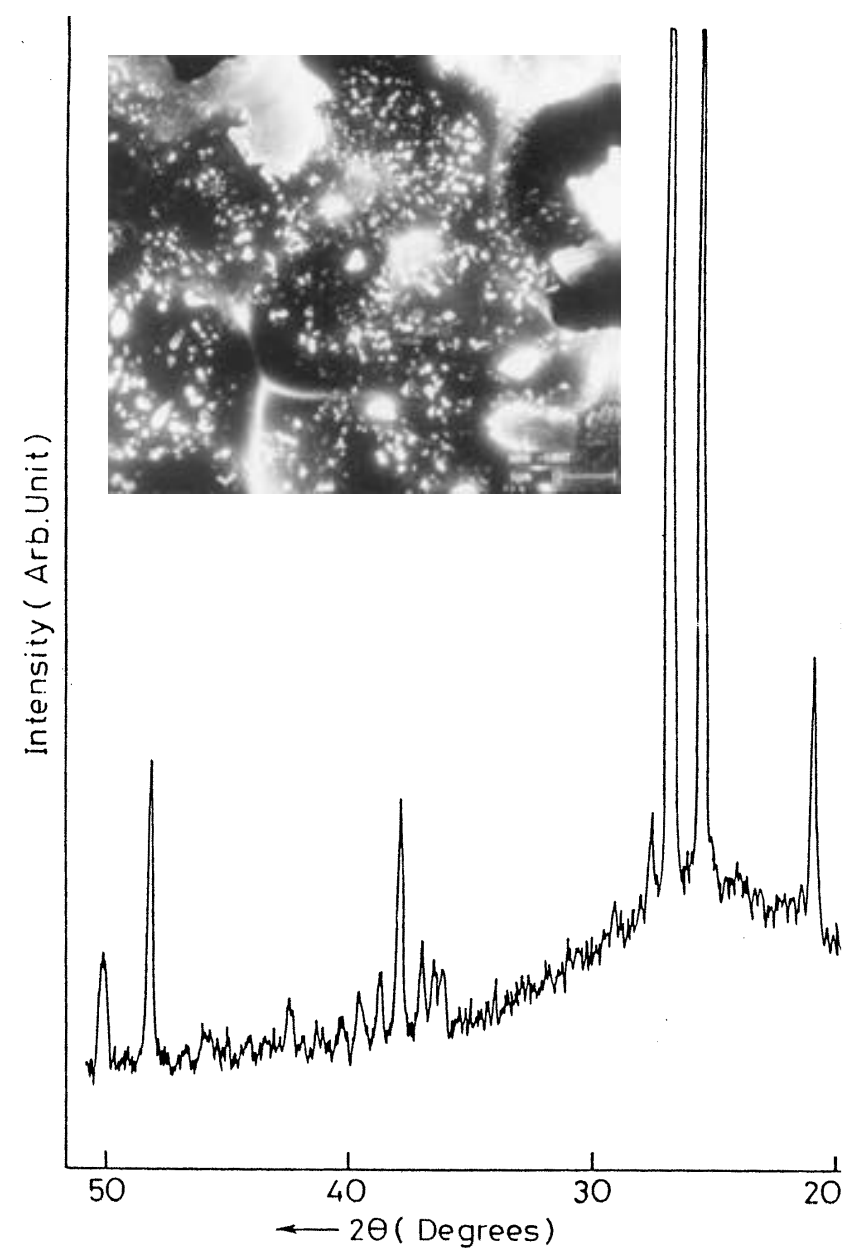

Figure 7. XRD pattern and scanning electron micrograph (inset) of heat-treated coating (composition no. 4 with $10 \%$ quartz).

(V) The coating is abrasion resistant and suitable for prevention of corrosive wear.

\section{Acknowledgements}

A part of this work was carried out in and with the help of School of Bio-Science and Engineering, Jadavpur University, Kolkata and their help is thankfully acknowledged. Thanks are due to Mrs S Sen for SEM studies, Dr A Chakravorty for X-ray analysis and all the colleagues of Glass-Ceramic Coating Division, for help.

\section{References}

Andrews A I 1961 Porcelain enamels (Illinois, USA: The Garard Press)

Behrenbeck H and Patzke K 1985 Vitreous Enameller 36 43

Briggs J and White D 1974 Vitreous Enameller 2525 
Datta Someswar 1995 Handbook of ceramics (ed.) S Kumar (Calcutta: Kumar \& Associates) Vol. II, pp. 289299

Datta S 1998 Bull. Mater. Sci. 21421

Hulbert S F, Hench L L, Forbes D and Bowman L S 1982-83 Ceramurgia Int. 8-9 131

Maskal K A and White D 1986 Vitreous enamelling: A guide to modern enamelling practice (London: Institute of Ceramics, Pergamon Press)

Pal S, Bhadra N and Datta S 1989 Int. symposium on biomaterials in orthopaedics (Varanasi: BHU) p. 28

Pal S, Pal A, Datta S and Das S K 1990 Ninth southern biomedical engineering conference (Miami, Florida, USA: Florida International University)

Phipps K J 1985 Vitreous Enameller 361

Powder Diffraction File (revised) 1967 Pub. Joint Committee on Powder Diffraction Standards

Sen R, Datta S, Das S K and Basu S K 1989 Wear 130249

Svetlov V A, Pernov A A, Mirova T V and Bovkun N P 1983 Glass Ceramics 40574

Van Vlack Lawrence H 1977 Materials science for engineers (London: Addison-Wesley publishing Co) p. 486

Vargin V V 1966 Technology of enamels (London: Maclaren and Sons Ltd.) 